\title{
RELATION BETWEEN THE QUALITY OF FAMILY RELATIONS OF STUDENTS AND SELECTED FIELD OF STUDY
}

\author{
UDC 159.942.072-057.875:316.356.2]:378
}

\author{
Milica Tošić Radev, Dušan Todorović \\ University of Niš, Faculty of Philosophy, Department of Psychology, Niš, Serbia
}

\begin{abstract}
Early experience, forms of behaviour that parents expressed towards a child and the family environment in which a child grew up have a significant effect on the formulation of attitudes, needs and interests that later on influence professional orientation and the choice of occupation (Roe 1956).

The research was conducted on a sample of 448 students from 6 different faculties and attempt to examine the possible connection between the quality of family relationships of the student and his/her professional interests, evaluated through education type, i.e. through selection of the field of study. The quality of family relationships were operationalized by the Family quality of interactions scale - KOBI (Vulić Prtorić 2004). The results indicated differences in the expression of family dimensions between students of different faculties. The students of detached, technical sciences have a weaker feeling of having their mother's acceptance, while the individuals from the group of students with the strongest feeling of rejection from both parents choose the field of psychology for their studies. Our results indicate the existence of differences between the subsamples of students in their experience of the family that go beyond gender differences, and suggest the need for further, more detailed research which could discover deeper, inner initiators that guide an individual's choice of profession.
\end{abstract}

Key words: parental acceptance, parental rejection, family satisfaction, different faculties, professional interests.

\section{INTRODUCTION}

The family life begins with marriage, continues with the birth of children, the children growing up and leaving home. Family life is an important condition forming the basis for the further development of the child. However, the family is still the first circle in which the child lives, in which he gains his first experiences, develops his potential and his values; it is the environment in which he learns and builds relationships with other family members (Petani 2011).

Received June 18, 2016 / Accepted January 19, 2017

Corresponding author: Milica Tošić Radev

University of Niš, Faculty of Philosophy, Cirila i Metodija 2, 18000 Nišs, Serbia

E-mail: milica.tosic.radev@filfak.ni.ac.rs 
According to the one of more comprehensive theories postulated by Super (Super 1957), one of the most significant factors of professional development of an individual is the image of oneself (the self-concept). The evolution of the process of creating an image of oneself is essentially important for later professional development. To create an image of oneself, the interaction between the individual and his/her surrounding (familial and social) is of paramount importance.

On the basis of the results of empirical research, Anna Roe (Roe 1956) presented a theory of professional interests according to which needs, interests and attitudes formed in childhood represent crucial factors of choosing ones' future occupation. Early experience, forms of behaviour that parents expressed towards a child and the family environment in which child grew up have a significant effect on the formulation of attitudes, needs and interests that later on influence professional orientation and the choice of occupation. Children whose parents nurtured warmer relationships will prefer occupations that include interpersonal communication and working with other people. The dismissive attitudes of parents can lead children to occupations in which an individual deals primarily with objects and things.

Parental Acceptance - Rejection Theory (PART theory; Rohner 1986) is a theory of an individual's socialization and development. The basic postulate of the PART theory is that the psychological adjustment and functioning of children is directly influenced by the experienced parents' (mother's and father's) acceptance-rejection (Khaleque and Rohner 2002). Parent's acceptance and rejection create a dimension of parenthood defined as emotional warmth. This dimension or continuum is a place where all people could be differentiated from one another, since all of them experienced love of a lesser or higher degree provided by parents or caregivers during childhood. This dimension is related to the quality of affectional relations between parents and children, as well as with the physical, verbal and symbolic behaviour parents use to show their emotions. One part of this continuum is defined as a parent's acceptance and it is comprised of warmth, attention, care, the ability to please, nurture, support or, simply put, love that children can feel through interaction with their parents or caregivers. The other part of the continuum is defined as a parent's rejection and it can appear when there is absence or significant lack of positive emotions. Furthermore, it often includes the presence of various physical and psychological damaging effects and behaviour. Extensive cross-cultural research over the past fifty years (Rhoner, Khaleque, and Cournoyer 2009) revealed that parental rejection can be manifested in four ways: 1) cold and emotionless, as opposed to warm and emotional; 2) hostile and aggressive; 3 ) indifferent and neglectful; 4) undifferentiated rejection, a person's belief that his/her parents do not care about him/her, do not love him/her, although clear behavioural indicators of the inadequate relation towards the child are lacking.

A subtheory of the PART theory related to sociocultural systems also finds crosscultural evidence which prove that rejection or acceptance by parents can be connected to numerous sociocultural correlators. Primarily, the results of some research indicate that the preferences an individual develops toward an occupation can be related to the experience of rejection or acceptance felt during childhood (Aronoff 1967; Mantell 1974; Rohner 1986). Similarly, the theory of attachment shows the basic aspects of the ways in which cognition, behaviour, the quality of past memories, current events and future expectations are related (Zimmermann 2004; Scharf \& Maiseless 2007). It is interesting to note that most of the research was concerned with the analysis of relationship between a child and its parents, but without differentiating between the relations of mother-child and father-child, hence the focus was on the mother's behaviour. However, recent research indicate that a mother's and 
father's behaviour can have different effects on the psychological adjustment of a child (Veneziano 2000). Some researchers point out that a father's acceptance is just as important as that of a mother (Rohner 1998; Rohner and Veneziano 2001) and that a father's and mother's influence can have similar effects on the different aspects of a child's development (Rohner and Khaleque 2008; Veneziano 2000). For example, in one study (Stefanović Stanojević et al. 2012) it was determined that the father's level of education is a statistically significant predictor of children's success in many competences in the cognitive domain, while the mother's is not, which brings us back to the importance of the father's role in growth and development.

\section{THE METHOD}

\subsection{The goal of the research}

The problem of the research was the attempt to examine the possible connection between the quality of family interactions of the student and his/her professional interests, evaluated through education type, i.e. through selection of the field of study.

\subsection{The sample}

The research was conducted on a sample of 448 students, with an equal number of both males and females. The sample was comprised of students from 6 different faculties of the University of Nis, Serbia (Faculty of Economics (N=71, 32 - male, 39 - female), Faculty of Electronic Engineering ( $\mathrm{N}=81,70$ - male, 11 - female), Faculty of Mechanical Engineering $(\mathrm{N}=68,50$ - male, 18 - female), Faculty of Medicine ( $\mathrm{N}=75,20$ - male, 55 - female), Faculty of Natural Science and Mathematics (N=73, 42 - male, 31 - female) and Faculty of Philosophy -Department of Psychology ( $\mathrm{N}=80,10$ - male, 70 - female).

The respondents' age was from 18 to 29 in all the subsamples. While the subsamples of the students from the Faculty of Natural Science and Mathematics and Faculty of Economics are standardized by gender, males prevail at the Faculties of Mechanical and Electronic Engineering and females at the Department of Psychology and Faculty of Medicine.

\subsection{Instruments}

The quality of family interaction scale - KOBI (Vulić Prtorić 2004). The scale measures the interaction between a parent and a child on two different dimensions, most often described as acceptance (emotional warmth, intimacy) and rejection (control, emotional negligence, punishment). These two dimensions were conceptualized in accordance with the theory of parental acceptance and rejection formulated by Ronald Rohner (Rohner 1989, 1999, according to Vulić Prtorić 2004). The KOBI scale consists of 55 statements: 22 of which describe a child's relation to his mother, 22 of which describe a child's relation to his father and the remaining 11 statements refer to the general atmosphere in the family.

The scale includes 5 sub-scales: satisfaction with the relationship in one's own family, mother's acceptance, father's acceptance, mother's rejection and father's rejection. Acceptance is mirrored in positive emotional aspects of the parent-child relationship in the sense of mutual closeness, providing support, understanding and trust, as well as relative symmetry in the relationship in general. Rejection is characterized by various experiences of 
parental actions which come in different forms - from misunderstanding and excessive demands to negligence and punishments. Furthermore, negligence implies the child's feeling that parents are not interested in his/her existence, that they do not devote enough of their time and attention to him/her. Punishments imply all experiences of gratuitous accusations, inappropriate punishments for a child's mistakes or even the bad mood of parents that child experiences as rudeness. The sub-scale of family satisfaction examines the feelings of the respondent related to his/her family and family life in general.

The theoretical span on specific sub-scales is: father's/mother's acceptance from 10 to 50 and father's/mother's rejection from 12 to 60 . A higher score on a specific scale implies greater perception of one of the defined characteristics of family interactions (acceptance or rejection).

\section{RESULTS}

The analysis of variance (Table 1) determined that there are statistically significant differences in the expression of a mother's and father's acceptance, as well as a father's rejection in relation to the sub-categories of choice of faculty.

Table 1 Differences between students from different faculties in the expression of the dimension of the quality of family relationships

\begin{tabular}{lcc}
\hline Variables & $\mathrm{F}$ & $\mathrm{p}$ \\
\hline Satisfaction with one's family & 1.940 & .087 \\
Acceptance by one's mother & 3.129 & .009 \\
Rejection by one's mother & 1.373 & .233 \\
Acceptance by one's father & 3.896 & .002 \\
Rejection by one's father & 2.648 & .023 \\
\hline
\end{tabular}

When dimensions of family satisfaction and mother's rejection are taken into consideration, it was discovered that no significant differences between these subcategories exist.

Respondents grouped according to their choice of faculty were arranged by using the T-test on the dimensions of acceptance by one's mother and father and statistically significant differences were found (Table 2 and 3 ).

Table 2 Differences in level of acceptance by one's mother among respondents of different professional orientations

\begin{tabular}{|c|c|c|c|c|}
\hline & Faculty & Mean & SD & $\overline{\mathrm{p}}$ \\
\hline \multirow{8}{*}{ 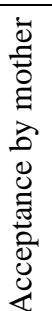 } & Faculty of Natural Sciences & 42.5479 & 6.98220 & \multirow{2}{*}{, 012} \\
\hline & Faculty of Electronic Engineering & 39.6875 & 6.88163 & \\
\hline & Faculty of Medicine & 43.6250 & 6.59158 & \multirow[b]{2}{*}{, 000} \\
\hline & Faculty of Electronic Engineering & 39.6875 & 6.88163 & \\
\hline & Faculty of Medicine & 43.6250 & 6.59158 & \multirow{2}{*}{, 014} \\
\hline & Faculty of Mechanical Engineering & 40.6912 & 7.39354 & \\
\hline & Faculty of Medicine & 43.6250 & 6.59158 & \multirow{2}{*}{,009 } \\
\hline & Faculty of Philosophy & 40.4125 & 8.15156 & \\
\hline
\end{tabular}


Our results show that students of the Faculty of Medicine give answers that indicate a more pronounced mother's acceptance than the students of the Faculty of Mechanical Engineering or Faculty of Philosophy. The obtained results also indicate that students of the Faculty of Electronic Engineering have lower scores on this dimension, on a statistically significant level, than the students of the Faculty of Natural Science and Mathematics and Faculty of Medicine.

Table 3. Differences in level of acceptance by one's father among respondents of different professional orientations

\begin{tabular}{|c|c|c|c|c|}
\hline & Faculty & Mean & SD & $\mathrm{p}$ \\
\hline \multirow{10}{*}{ 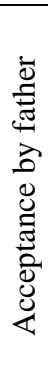 } & Faculty of Economics & 37.7571 & 8.40365 & \multirow{2}{*}{,018 } \\
\hline & Faculty of Philosophy & 34.3250 & 9.12886 & \\
\hline & Faculty of Electronic Engineering & 37.8519 & 9.09823 & \multirow{2}{*}{,015 } \\
\hline & Faculty of Philosophy & 34.3250 & 9.12886 & \\
\hline & Faculty of Mechanical Engineering & 38.9559 & 8.89144 & \multirow{2}{*}{, 002} \\
\hline & Faculty of Philosophy & 34.3250 & 9.12886 & \\
\hline & Faculty of Medicine & 39.9730 & 7.57605 & \multirow{2}{*}{,000 } \\
\hline & Faculty of Philosophy & 34.3250 & 9.12886 & \\
\hline & Faculty of Natural Sciences & 38.6575 & 8.65258 & \multirow{2}{*}{,003 } \\
\hline & Faculty of Philosophy & 34.3250 & 9.12886 & \\
\hline
\end{tabular}

The results presented in the Table 3 show that significant differences exist between the arithmetic means of groups of students which differ according to the faculty choice in relation to the dimension of the father's acceptance. It was determined that the students of the Faculty of Philosophy experience their father's acceptance to a lesser extent than the respondents from the Faculty of Economics, Faculty of Electronic Engineering, Faculty of Mechanical Engineering, Faculty of Medicine and Faculty of Natural Science and Mathematics.

Table 4 Differences in the level of rejection by the father among respondents of different professional orientations

\begin{tabular}{|c|c|c|c|c|}
\hline & Faculty & Mean & SD & $\mathrm{p}$ \\
\hline \multirow{12}{*}{ 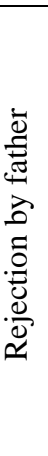 } & Faculty of Electronic Engineering & 22.6173 & 9.92039 & \multirow{2}{*}{023} \\
\hline & Faculty of Mechanical Engineering & 19.2794 & 7.77836 & \\
\hline & Faculty of Electronic Engineering & 22.6173 & 9.92039 & \multirow{2}{*}{,025 } \\
\hline & Faculty of Medicine & 19.1667 & 8.80621 & \\
\hline & Faculty of Electronic Engineering & 22.6173 & 9.92039 & \multirow{2}{*}{038} \\
\hline & Faculty of Natural Sciences & 19.6164 & 7.81493 & \\
\hline & Faculty of Mechanical Engineering & 19.2794 & 7.77836 & \multirow[b]{2}{*}{,018 } \\
\hline & Faculty of Philosophy & 22.7000 & 9.68282 & \\
\hline & Faculty of Medicine & 19.1667 & 8.80621 & \multirow{2}{*}{020} \\
\hline & Faculty of Philosophy & 22.7000 & 9.68282 & \\
\hline & Faculty of Natural Sciences & 19.6164 & 7.81493 & \multirow{2}{*}{,031 } \\
\hline & Faculty of Philosophy & 22.7000 & 9.68282 & \\
\hline
\end{tabular}

Also, it was determined (Table 4) that the students of the Faculty of Electronic Engineering have significantly higher scores on the dimension of the father's rejection than 
students of the Faculty of Mechanical Engineering, Faculty of Medicine and Faculty of Natural Science and Mathematics. Respondents who attend the Faculty of Philosophy experience the father's rejection to a greater extent than the respondents who attend the Faculty of Mechanical Engineering, Faculty of Medicine and Faculty of Natural Science and Mathematics.

With a view to checking whether the professional orientation may be discriminated on the basis of components of the quality of family interactions, we applied the method of the canonical discriminant analysis.

Table 5 Chi square of canonical discriminant functions

\begin{tabular}{lcccccc}
\hline Function & Eigenvalue & Canonical R & Wilks lambda & Chi square & df & p-level \\
\hline 1 &, 091 & .288 & .859 & 51.78 & 20 & .000 \\
2 &, 036 & .187 & .938 & 22.29 & 12 & .034 \\
\hline
\end{tabular}

Applying the canonical discriminant analysis suggested the existence of two functions that discriminated different groups of students (Table 5). The results show that on the basis of dimensions of family interactions quality is possible to discriminate between students of different faculties. Specifically, in Table 6 it can be seen that the first allocated function is a characteristic of the students of psychology, while the second discriminant function is a characteristic of the students of the Faculty of Electronic Engineering.

Table 6 Functions at group centroids of canonical discriminant functions

\begin{tabular}{lcc}
\hline Faculty & Function I & Function II \\
\hline Faculty of Economics &,- 001 & .096 \\
Faculty of Electronic Engineering &, 310 & .272 \\
Faculty of Mechanical Engineering & .213 & -.182 \\
Faculty of Natural Sciences & .094 & -.225 \\
Faculty of Philosophy & -.431 & .055 \\
\hline
\end{tabular}

Table 7 shows the matrix structure of isolated discriminatory functions.

Table 7 Structure matrix of canonical discriminant functions

\begin{tabular}{lcc}
\hline I function & & \\
\hline Satisfaction with one's family & .428 & \\
Acceptance by one's mother & -.057 & \\
Rejection by one's mother & -.374 & $\mathrm{p}^{\dagger}<.05$ \\
Acceptance by one's father & .762 & \\
Rejection by one's father & -.308 & $\mathrm{p}^{\dagger}<.05$ \\
\hline II function & -.518 & $\mathrm{p}^{\dagger}<.05$ \\
\hline Satisfaction with one's family & -.648 & \\
Acceptance by one's mother & .636 & $\mathrm{p}^{\dagger}<.05$ \\
Rejection by one's mother & .434 & \\
Acceptance by one's father & .903 & \\
Rejection by one's father &
\end{tabular}


As it can be seen from the table, psychology students are best defined by the experience of not acceptance by one's father, while the students of electronic engineering can be well discriminated from the rest of the respondents, based on the high not acceptance of one's mother, the rejection by one's father and overall dissatisfaction with family.

Given the fact that the subsamples of respondents who are studying at different faculties differ significantly in terms of gender structure, it was necessary to check whether there are gender differences in the experience of acceptance or rejection by one's parents and family satisfaction, which can be a variable that mediates the connection between the experienced quality of family relations and selected field of study.

Table 8 Gender differences on family relationships quality dimensions

\begin{tabular}{|c|c|c|c|c|}
\hline Family relationships quality dimension & Gender & Mean & SD & $\mathrm{p}$ \\
\hline \multirow{2}{*}{ Satisfaction with one's family } & Male & 47.19 & 7.38 & \multirow{2}{*}{,807 } \\
\hline & Female & 47.01 & 8.11 & \\
\hline \multirow{2}{*}{ Acceptance by one's mother } & Male & 40.54 & 6.91 & \multirow{2}{*}{, 010} \\
\hline & Female & 42.32 & 7.59 & \\
\hline \multirow{2}{*}{ Rejection by one's mother } & Male & 20.14 & 7.58 & \multirow{2}{*}{,473 } \\
\hline & Female & 19.58 & 8.60 & \\
\hline \multirow{2}{*}{ Acceptance by one's father } & Male & 39.13 & 8.62 & \multirow{2}{*}{,002 } \\
\hline & Female & 36.58 & 8.80 & \\
\hline \multirow{2}{*}{ Rejection by one's father } & Male & 21.44 & 9.26 & \multirow{2}{*}{, 285} \\
\hline & Female & 20.50 & 9.10 & \\
\hline
\end{tabular}

The results show that there are no significant differences between male and female students in their experience of rejection by one's parents and overall satisfaction with one's family, but there are statistically significant differences in the feelings of acceptance by both of parents. In fact, our results show that females, compared to males, experience greater acceptance by the mother, while males report better acceptance by the father.

\section{DISCUSSION AND CONCLUSIONS}

A great number of significant differences in dimensions of family relationships among students of different faculties is an interesting result. Although it is expected that students of different professional orientations share certain common characteristics, it was significant to discover that there are differences among them regarding the feeling of parental rejection or acceptance. If we consider differences in the feelings of the mother's acceptance, it was determined that the students of Faculty of Electronic Engineering, Mechanical Engineering and Faculty of Philosophy have a weaker experience of the mother's acceptance than the students of other faculties. In addition, students of the Faculty of Electronic Engineering and Faculty of Philosophy have a stronger feeling of the father's rejection, and furthermore, students of the latter faculty have by far the least experience of the father's acceptance.

The sample of students of the Faculty of Philosophy was comprised of the students from the Psychology Department, which can indicate that these young people choose psychology as the field of interest in order to get to know themselves better and even find answers to some traumatic experiences from childhood - for themselves or for the other people. 
Moreover, students of technical faculties have a weaker feeling of the mother's acceptance and even dissatisfaction with their family.

With the uttermost caution in the process of making a conclusion, our results indicate the need for further research of this phenomenon, i.e. the fact that the students of cold, technical sciences have a weaker feeling of their mother's acceptance, while the individuals from the group of students with the strongest feeling of rejection from both parents choose the field of psychology for their studies. This is in accordance with previous results that early experiences with parents and the overall family environment in which the child grew up have a significant effect on the formulation of attitudes, needs and interests that later on influence professional orientation and the choice of occupation. Namely, dismissing attitudes of parents can lead children to occupations in which an individual deals primarily with objects and things or motivates the child to study psychology. These results are in accordance with the results of some studies which indicate that the preferences an individual develops toward an occupation can be related to the experience of rejection or acceptance felt during childhood (Aronoff 1967; Mantell 1974; Rohner 1986).

When gender differences in the student population are taken in consideration we can conclude that they only partially mediate results, but not completely. Since students of the Faculty of Electronic Engineering are predominantly males and students of Psychology are mostly females, the differences that were obtained in relation to the experience of acceptance by parents may be related to gender structure rather than choice of faculty. However, given that the differences were found within faculties where the student population is standardized by gender (e.g. Faculty of Medicine), and more importantly that differences were found on dimensions of rejection by the father and family satisfaction, where no gender differences exist, we can conclude that the resulting difference cannot be fully explained by gender differences in the student population.

In fact, there is a connection between the quality of family relations and selected field of study. The students of cold, technical sciences have weaker feelings of their mother's acceptance, while the individuals from the group of students with the strongest feeling of rejection from both parents chose the field of psychology for their studies.

A very important result is that one's father's acceptance and rejection is just as important as that of the mother's and that one's father's and mother's influence can have similar effects, as along with satisfaction with family life in general, on the children's professional orientation.

The results of our research cannot however predict outcomes, they indicate the existence of differences that it would be interesting to examine further.

Acknowledgement: Prepared as a part of the project 179013, supported by the Ministry of Education and Science of the Republic of Serbia.

\section{REFERENCES}

Aronoff, Joel. Psychological Needs and Cultural Systems: A Case Study. Princeton, NJ: D. Van Nostrand, 1967. Khaleque Abdul \& Ronald Rohner. „Perceived Parental Acceptance-rejection and Psychological Adjustment: A Meta-analysis of Cross-cultural and Intracultural Studies”. Journal of Marriage and Family 64 (2002): 54 64. DOI: $10.1111 / \mathrm{j} .1741-3737.2002 .00054 . x$.

Mantell, David. True Americanism: Green Berets and War Resisters: A Study of Commitment. New York, NY: Teachers College Press, 1974. 
Petani, Rozana. "Correlation Between Family Interaction and Adolescents' Attitudes”. Andragoška spoznanja 17 (2011):10-22.

Roe, Anne. The Psychology of Occupations. New York, NY: John Wiley \& Sons, 1956.

Rohner, Ronald. The Warmth Dimension: Foundations of Parental Acceptance-rejection Theory. Beverly Hills, CA: Sage Publications, Inc, 1986.

Rohner, Ronald. Parental Acceptance and Rejection Bibliography. Storrs, CT: University of Connecticut, Center for the Study of Parental Acceptance and Rejection, 1998.

Rohner, Ronald \& Robert Veneziano. "The Importance of Father Love: History and Contemporary Evidence". Review of General Psychology 5 (2001): 382-405. DOI: 10.1037/1089-2680.5.4.382.

Rohner, Ronald \& Abdul Khaleque. „Relations Between Perceived Partner and Parental Acceptance”. In Family Relations: 21st Century Issues and Challenges, edited by J. K. Quinn, and I. G. Zambini. New York, NY: Nova Science Publishers, Inc, 2008.

Rohner, Ronald, Abdul Khaleque, and D. E. Cournoyer. Introduction to Parental Acceptance-rejection Theory, Methods, Evidence and Implications, 2009. Retrieved from: http://www.cspar.uconn.edu/introduction\%20 to\%20parental\%20acceptance_09.pdf (25. 2. 2013).

Scharf, Miri, and Ofra Mayseless. "Adolescents' Attachment Representations and their Capacity for Intimacy in Close Relationships". Journal of Research on Adolescence 17 (2007): 23-50. DOI: 10.1111/j.15327795.2007.00511.x.

Stefanović Stanojević, Tatjana, Ivana Mihić, \& Nataša Hanak. Afektivna vezanost i porodični odnosi: razvoj $i$ značaj. Beograd: Centar za primenjenu psihologiju, 2012.

Super, Donald. Vocational Development. New York, NY: Teachers College Press, 1957.

Veneziano, Robert. "Perceived Paternal and Maternal Acceptance and Rural African American and European American Youths' Psychological Adjustment”. Journal of Marriage and Family 62 (2000): 123-132. DOI: 10.1111/j.1741-3737.2000.00123.x.

Vulić Prtorić, Anita. "Skala kvalitete obiteljskih interakcija". Zbirka psihologijskih skala i upitnika II. Zadar: Sveučilište u Zadru, 2004.

Zimmermann, Peter. Attachment Representations and Characteristics of Friendship relating During Adolescence. Journal of Experimental Child Psychology 88 (2004): 83-101. DOI:10.1016/j.jecp.2004.02.002

\section{POVEZANOST OBLASTI STUDIRANJA I KVALITETA PORODIČNIH ODNOSA STUDENATA}

Rano iskustvo, ponašanje roditelja prema deci i uopšte porodično okruženje u kojem se odrasta imaju značajan uticaj na formiranje stavova, potreba i interesovanja koji kasnije utiču i na profesionalnu orijentaciju i izbor zanimanja mladih (Roe 1956).

Istraživanje je sprovedeno na uzorku od 448 studenata sa 6 različitih fakulteta. Problem istraživanja je ispitivanje moguce povezanosti između kvaliteta porodičnih odnosa studenata i njegovih/njenih profesionalnih interesovanja, određenih preko odabrane oblasti studiranja. Kvalitet porodičnih odnosa je operacionalizovan Skalom kvaliteta porodičnih odnosa - KOBI (Vulić Prtorić 2004).

Rezultati su pokazali razlike u doživljaju porodičnih odnosa kod studenata različitih fakulteta. Konkretno, studenti hladnih, tehničkih nauka imaju slabiju osećaj prihvatanja majke, dok studenti koje karakteriše najjači doživljaj odbačenosti od strane oba roditelja studiraju studije psihologije.

Rezultati ukazuju na postojanje razlika, koje se ne mogu objasniti samo razlikama u polnoj strukturi studentske populacije različitih fakulteta, u doživljaju porodičnih odnosa. Sve ovo ukazuje na potrebu za daljim detaljnijim istraživanjima koja bi mogla da otkriju dublje, unutrašnje motive izbora zanimanja.

Ključne reči: prihvatanje i odbacivanje od strane roditelja, zadovoljstvo porodicom, fakultet, profesionalna interesovanja. 